\title{
ORIGIN AND DISTRIBUTION OF FEMORAL NERVES IN SWINE (Sus scrofa domesticus LINNEAUS, 1758) FETUSES FROM CROSSES OF DAN BRED AND AGPIC-337 LINES
}

\author{
ORIGEM E DISTRIBUIÇÃO DOS NERVOS FEMORAIS EM FETOS SUÍNOS (SuS \\ scrofa domesticus LINNEAUS, 1758) DO CRUZAMENTO DAS LINHAGENS DAN \\ BRED E AGPIC337
}

\author{
Gustavo Cavinato HERRERA ${ }^{1}$; Frederico Ozanam CARNEIRO E SILVA ${ }^{\mathbf{1}}$; \\ Lázaro Antonio dos SANTOS'; Lorena Tannus MENEZES'; Flávio Machado de MORAES1 \\ 1. Department of Animal Anatomy, Faculty of Veterinary Medicine, Federal University of Uberlandia, Uberlândia, MG, \\ Brazil;
}

\begin{abstract}
The objective of this work was to assess the origin and distribution of femoral nerves in 30 swine fetuses from crosses of Dan Bred and AGPIC-337 lines. Thirty animals-fifteen males and fifteen females-from the collection of the Faculty of Veterinary Medicine's Animal Anatomy Laboratory of the Federal University of Uberlândia, Uberlândia MG, Brazil, were used. The animals were fixed by injecting a $10 \%$ aqueous formaldehyde solution into the descending aorta artery and thoracic, abdominal, pelvic and intramuscular cavities. The specimens were then submerged in a solution with the same concentration. These animals have five to seven lumbar vertebrae. The number of lumbar vertebrae was six in $96.67 \%$ and seven in $3.33 \%$ of the animals. The femoral nerve originated from the L4 and L5 (66.67\%), L5 and L6 (26.67\%) and L3 and L4 (6.66\%) lumbar vertebrae. It sent branches to the psoas major, psoas minor, iliac, pectineus, and quadriceps femoris muscles in all animals, to the sartorius in $43.33 \%$ and to the gracilis in $6.66 \%$ of animals. No marked differences were found in the characteristics of origin and distribution of the femoral nerve between the swine fetuses from crosses of Dan Bred and AGPIC-337 lines and the animals described in the literature.
\end{abstract}

KEYWORDS: Peripheral nervous system. Lumbosacral plexus. Anatomy.

\section{INTRODUCTION}

Pig farming is one of the main activities of agribusiness in Brazil by generating income and jobs that contribute to the country's economy; it has an annual production of about 3.5 million $\mathrm{Mg}$ that represents more than US\$ 8 billion of income, and is constantly seeking to increase its production and profitability levels (PORTAL DO AGRONEGÓCIO, 2015).

Dan Bred is a Danish line originated from the cross between the Landrace and Large White breeds whose females have good productivity and early maturity. The Agroceres-PIC (AGPIC-337) is a commercial line originated from crosses including the Pietrain and Duroc breeds, whose males are used in crosses with Dan Bred for improvement of productivity (FRANÇA, 2015).

Therefore, information about anatomical structures, especially nerve structures, allows diagnose of lesions, determination of their location and prognosis and assists in surgical and anesthetic practices (ROSA, 2012).

The lumbosacral plexus originates nerves that are distributed to the pelvic limbs. It is formed by the last lumbar spinal nerves and first sacral spinal nerves. The origin and distribution of nerves from the lumbosacral plexus is object of study in different species and breeds, since the femoral nerve is one of the main nerves originated from them (GOMES et al., 2013).

The increase in the precocity of animals, which affects their speed of growth and productive and reproductive life, has led researches on possible anatomical variations in the current lineages (SANTOS et al., 2013). Thus, the objective of this work was to assess the origin and distribution of femoral nerves in 30 swine fetuses from crosses of Dan Bred and AGPIC-337 lines.

\section{MATERIAL AND METHODS}

Thirty swine (Sus scrofa domesticus, L., 1758) animals, fifteen males and fifteen females, from the collection of the Faculty of Veterinary Medicine's Animal Anatomy Laboratory of the Federal University of Uberlândia, Uberlândia MG, Brazil, were used.

The animals were fixed by injecting a $10 \%$ aqueous formaldehyde solution into the descending aorta artery and thoracic, abdominal, pelvic and intramuscular cavities. The specimens were then submerged in a solution with the same concentration. 
An incision was made in the ventral midline from the xiphoid cartilage of the xiphoid process of the sternum bone to the pelvic symphysis to assess the origins of the femoral nerve. Then, four other transverse incisions were made, two in each antimere, until reaching the dorsal median line.

Subsequently, the pelvic symphysis was disarticulated. Part of the adipose tissue was removed and the psoas minor muscles were fold to observe the ventral branches of the lumbar spinal nerves of both antimeres.

The nomenclature adopted for the anatomical description followed the International Committee on Veterinary Gross Anatomical Nomenclature (I.C.V.G.A.N. 2017).

The statistical analysis of the data was descriptive in terms of simple percentage. The Mann-Whitney test was used to evaluate the statistical differences between the frequencies of the origin of the femoral nerve in both antigens in relation to the sex of the animals. The level of follow-up has been stablished at 5\% ( $\mathrm{p}<0.05)$.

The work has been approved under the registration number 094/14 by the Committee on Ethics Animal Use (CEUA) linked to the Research and Postgraduate Pro-rectory (PROPP) of the Federal University of Uberlândia.

\section{RESULTS}

Seven lumbar vertebrae were found in one animal $(3.33 \%)$ and six in $29(96.67 \%)$ animals. The femoral nerve originated from the ventral branches of the lumbar spinal nerves from L3 to L6 lumbar vertebrae, with symmetry in both antimeres. It originated from L4 and L5 in $20(66.67 \%)$, from L5 and L6 in $8(26.67 \%)$, and from L3 and L4 in 2 $(6.66 \%)$ animals (Figure 1 and 2).

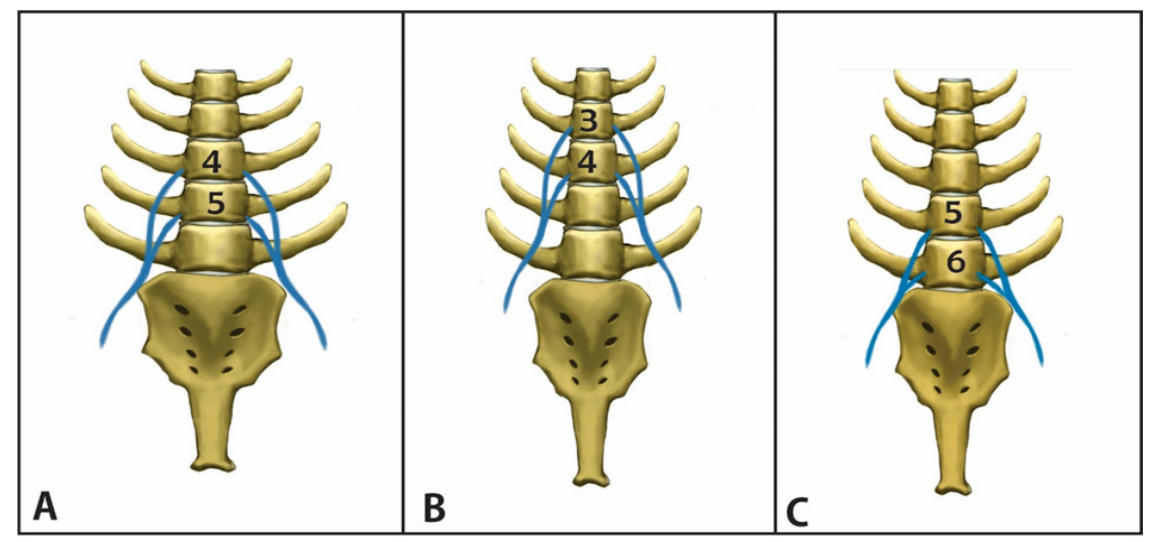

Figure 1. Schematic drawing of the lumbar and sacral region of swine (Sus scrofa domesticus L. 1758) animals from crosses of Dan Bred and AGPIC-337 lines, representing origin of the femoral nerve. A) L4 and L5 (66.67\%), B) L3 and L4 (6.66\%), and C) L5 and L6 (26.67\%) lumbar vertebrae.

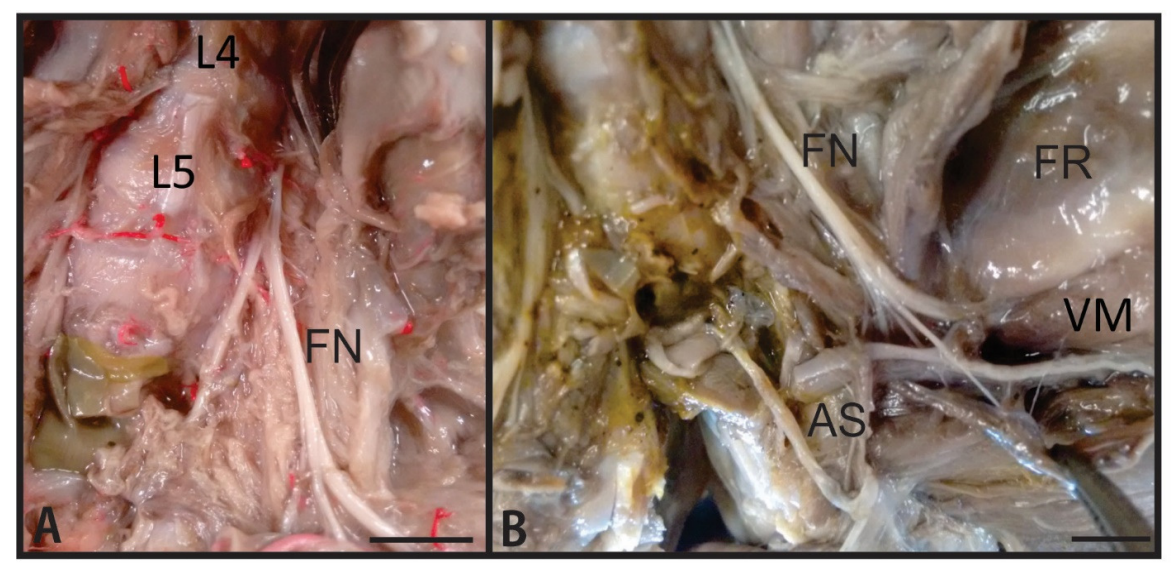

Figure 2. Ventral view of the lumbar and sacral regions of swine (Sus scrofa domesticus L., 1758) animals from crosses of Dan Bred and AGPIC-337 lines, showing the A) origin of the femoral nerve (FN) from the ventral branches of the fourth and fifth lumbar spinal nerves, fourth lumbar vertebra (L4), fifth lumbar vertebra (L5); and the B) distribution of the femoral nerve (FN) in the rectus femoris $(\mathrm{RF})$, sartorius (AS) and vastus medialis (VM) muscles. Scale bar $=1 \mathrm{~cm}$. 
The femoral nerves were distributed symmetrically to the psoas major, psoas minor, iliac, pectineus, and quadriceps femoris muscles in all animals, to the sartorius in $43.33 \%$ (13 animals) and to the gracilis in $6.66 \%$ ( 2 animals), with the saphenous nerve emitted in the thigh region.

\section{DISCUSSION}

Six lumbar vertebrae were found in 29 swine (Sus scrofa domesticus, L., 1758) specimens from crosses of Dan Bred and AGPIC-337 lines. Similar results were found by Ghoshal (1986) and Mihelic et al. (2004) in swine, Silva et al. (2007) in the AGA1050 swine line, Rosa (2012) and Santos et al. (2013) in the Pen Ar Lan swine line, and Gomes et al. (2013) in boars. However, one animal presented seven lumbar vertebrae this experiment. This result was also found by Mihelicet al. (2004) in swine, Rosa (2012) and Santos et al. (2013) in the Pen Ar Lan swine line, and Gomes et al. (2013) in boars.

In the specimens of this study, the femoral nerve originates from the cranial part of the lumbosacral plexus, runs ventrally and caudally to the major and minor psoas muscles leaves the pelvic cavity, reaches the medial region of the thigh where it gives rise to the saphenous nerve and several other branches that are distributed in the structures, corroborating with (GETTY, 1986). Dyce, Sack and Wensing (2004) and Tonni et al. (2014) described that lesions of nerves that compose the lumbosacral plexus, generate locomotor difficulties and even limb paresis.

The femoral nerve originated from L3 to L6, with origin in the L4 and L5 in $66.67 \%$ of the animals, confirming the results of Getty (1986) for this species. The femoral nerve originated from the ventral branches of the L4 and L5 in 20 animals (66.67\%), confirming the results found by Mihelicet al. (2004) in swine, Silva et al. (2007) in AG1050 swine line, Moraes et al. (2008) in non-breed equines, Lizardo et al. (2009) in a zebu-crossed bovine fetus, and Rosa (2012) in a Pen Ar Lan swine fetus.

The femoral nerve originated from L5 and L6 in $8(26.67 \%)$ animals. Similar results were found by Mihelicet al. (2004) in swine, Tonini et al. (2014) in paca (Cuniculus paca L., 1758), Nascimento et al. (2015) in Saanem goats, and Silva et al. (2011) in non-breed sheep.

The femoral nerve originated from L3 and L4 in two animals (6.66\%). This result is in agreement with the data reported by Mihelicet al. (2004) in swine, Moraes et al. (2008) and Gomes et al. (2013) in boars, and Souza (2012) in an anteater (Myrmecophaga tridactyla L., 1758).

According to the femoral nerve distribution, it emitted branches to the psoas major, psoas minor, and iliac muscles, as also found by Schwarze and Schroder (1970) and Dyce, Sack and Wensing (2004) in ruminants, and Getty (1986) in bovines.

The distribution of the femoral nerve to the quadriceps femoris was observed in the 30 dissected animals. This result is in agreement with those found by Evans and de Lahunta (2001) in dogs, Mihelicet al. (2004) in swine, Silva et al. (2007) in the AG1050 swine line, Moraes et al. (2008) in nonbreed equines, Lizardo et al. (2009) in a zebucrossed bovine fetus, Silva et al.(2011) in non-breed sheep, Rosa (2012) in a Pen Ar Lan swine fetus, and Nascimento et al. (2015) in Saanen goats.

All animals had distribution of the femoral nerve to the psoas minor muscle-as found by Evans and de Lahunta (2001) in dogs, Moraes et al. (2008) in non-breed equines, and Nascimento et al. (2015) in Saanen goats-and to the psoas major muscle-as found by Evans and de Lahunta (2001) in dogs, Lizardo et al. (2009) in a zebu-crossed bovine fetus, Silva et al.(2011) in non-breed sheep, Rosa (2012) in a Pen Ar Lan swine fetus, Gomes et al. (2013) in boars, and Nascimento et al. (2015) in Saanen goats.

Branches of the femoral nerve to the iliac muscle were also found in the 30 animals studied. This result is similar to those found by Lizardo et al. (2009) in a zebu-crossed bovine fetus, Silva et al. (2011) in non-breed sheep, and Gomes et al. (2013) in boars.

All animals had distribution of the femoral nerve to the pectineus muscle - as found by Silva et al. (2007) in the AG-1050 swine line, and Lizardo et al. (2009) in zebu-crossed bovine fetuses, and different from the results of Gomes et al. (2013) in boars, who found no branches to this muscle.

Branches of the femoral nerve to the sartorius muscle were found in $43.33 \%$ of the animals. This result agrees with those found by Silva et al. (2007) in the AG1050 swine line, Silva et al. (2011) in non-breed sheep, Rosa (2012) in a Pen Ar Lan line swine fetus, Gomes et al. (2013) in boars, and Nascimento et al. (2015) in Saanen goats.

Two animals $(6.66 \%)$ presented distribution of the femoral nerve to the gracilis muscle, as found by Silva et al. (2007) in the AG1050 swine line, and Moraes et al. (2008) in non-breed equines.

The femoral nerve of the thirty animals studied had branches to the quadriceps femoris muscle, and then it emitted the saphenous nerve; this result agrees with the findings of Silva et al. 
Origin and distribution...

(2007) in the AG1050 swine line, and Rosa (2012) in the Pen Ar Lan swine line.

The swine (Sus scrofa domesticus, L., 1758) fetuses from crosses of Dan Bred and AGPIC-337 lines presented similar number of vertebrae, and similar origins and distribution of the femoral nerve to those found in the literature.

\section{CONCLUSIONS}

Swine (Sus scrofa domesticus L., 1758) fetuses from crosses of Dan bred and AGPIC-337 lines have five to seven lumbar vertebrae, and their
HERRERA, G. C. et al.

femoral nerve originated from the L4 to L6 lumbar vertebrae and distributed to the psoas major, psoas minor, iliac, pectineus, quadriceps femoris, sartorius and gracilis muscles.

No differences were observed between the frequency of origin of the femoral nerve in both antigens in relation to the sex of the animals.

No marked differences were found in the characteristics of origin and distribution of the femoral nerve between the swine fetuses from the crosses of Dan Bred and AGPIC-337 lines and animals described in the literature.

RESUMO: Objetivou-se estudar a origem e distribuição dos nervos femorais em 30 fetos suínos oriundos do cruzamento das linhagens Dan Bred e AGPIC337. Foram utilizados 30 animais, quinze machos e quinze fêmeas, pertencente ao acervo do laboratório de Anatomia Animal da Faculdade de Medicina Veterinária da Universidade Federal de Uberlândia. A fixação dos animais se deu por meio de injeção de solução aquosa de formaldeído a $10 \%$ na artéria aorta parte descendente, cavidades torácica, abdominal, pélvica e intramusculares, em seguida, os espécimes foram submersos em solução contendo a mesma concentração. Esses animais possuem cinco a sete vértebras lombares. Em 96,67\% dos animais o número de vértebras lombares foi seis e em 3,33\% sete. O nervo femoral originou-se de L4 e L5 (66,67\%), L5 e L6 (26,67\%) e L3 e L4 (6,66\%). Emitiu ramos para os músculos psoas maior, psoas menor, ilíaco, pectíneo, quadríceps femoral em $100 \%$ dos casos, $43,33 \%$ para o sartório e 6,66\% para o grácil. Nota-se que não foram observadas diferenças marcantes nas características tanto na origem como na distribuição do nervo femoral entre os fetos de suínos oriundos do cruzamento das linhagens Dan Bred e AGPIC337 e os animais da literatura consultada

PALAVRAS-CHAVE: Sistema nervoso periférico. Plexo lombossacral. Anatomia.

\section{REFERENCES}

DYCE, K. M.; SACK, W. O.; WENSING, C. J. G. Tratado de anatomia veterinária. 3. ed.Rio de Janeiro: Guanabara Koogan, 2004.872p.

EVANS, H. E.; LAHUNTA, A. Guia para a dissecação do cão. 5.ed. Rio de Janeiro : Guanabara Koogan, 2001.103-107p.

FRANÇA, G. L. M. Origem e distribuição do nervo axilar em feto de suínos (Susscrofadomesticus, LINNEAUS, 1758) do cruzamento das linhagens Dan Bred e AGPIC-337. 2015. Dissertação, 2015, 41f, Universidade Federal de Uberlândia, Uberlândia, 2015.

GETTY, R. Sisson / Grosman. Anatomia dos animais domésticos. 5 ed. Rio de Janeiro: Guanabara Koogan, 1986, v. 1, 1134p.

GETTY, R. Sisson / Grosman. Anatomia dos animais domésticos. 5 ed. Rio de Janeiro: Guanabara Koogan, 1986, v. 2, 2000p.

GOMES, A. R. A et al. Origens e ramificações do nervo femoral em javalis(SusscrofascrofaLINNEAUS, 1758). 2013. Bioscience Journal, Uberlândia, v.29, n. 3, p.727-731. 2013.

INTERNATIONAL COMMITTEE ON VETERINARY GROSS ANATOMICAL NOMENCLATURE.Nomina anatômica veterinária. 6 ed. (Revised version), Wava. 2017. 160p.

LOPES, J. A et al. Morfologia do plexo lombossacral da jaguatirica (Leoparduspardalis). 2012. Biotemas, Florianópolis, v. 25, n. 4, p.215-220. 2012 . 
LIZARDO, F. B et al. Origin and distribution of the femoral nerve in fetuses of zebu-

crossedbovines.2009.Brazilian Journal of Morphology Science, São Paulo, v.26, n. 2, p. 91-96, 2009.

MIHELIC, D. et al. Variations of formation of $\mathrm{n}$. femoralis, $\mathrm{n}$. obturatorius and $\mathrm{n}$. ischiadicus in pigs.

Veterinarski Arhiv, Croácia, v. 74, n. 4, 261-270. 2004.

MORAES, D.V et al. Origem e distribuição do nervo femoral em equinos sem raça definida. Horizonte Científico, Uberlândia, v.1, n. 9, p.1-10. 2008.

NASCIMENTO, R. M et al. Origem e distribuição antimérica dos nervos femorais em caprinos recém-natos da raça Saanen.2015. Ciência animal brasileira, Goiânia, v.16, n. 2, p. 251-261. 2015

ROCHA, L. M. S.; MASSONE, F. Estudo anatomo-anestesiológico do segmento lombar (L1 a L6) em cães Brazilian Journal of Veterinary Research and Animal Science, São Paulo, v. 43, n. 2, p. 167-177, 2006.

ROSA, L. A. Origem e distribuição dos nervos femorais em de fetos suínos(Susscrofadomesticus, LINNEAUS, 1758) da linhagem Pen Ar Lan. 2012. Dissertação, 2012, 56f, Universidade Federal de Uberlândia, Uberlândia, 2012.

SANTOS et al. Origem e distribuição do nervo isquiático em fetos de suínos (Sus Scrofa domesticus- Linnaeus, 1758) da linhagem Pen Ar Lan, Biotemas, Florianópolis, v. 26, n. 1, p. 147-157, 2013.

SILVA, F. O. C et al. Origens e distribuições dos nervos femorais em ovinos sem raça definida. Bioscience Journal, Uberlândia, v. 27, n. 6, p. 978-981. 2011.

SILVA, F. O. C et al. Origem e distribuição do nervo femoral em suínos (Susscrofadomesticus - Linnaeus, 1758) da linhagem AG-1050. In: CONGRESSO ASSOCIAÇÃO BRASILEIRA DE VETERINÁRIOS ESPECIALISTAS EM SUÍNOS, 13, 2007,Anais... Florianópolis, ABRAVES, 2007.

SOUZA, T. A. M. Origens, distribuições e ramificações dos nervos femorais no tamanduá bandeira(Myrmecophagatridactyla LINNEAUS 1758). Dissertação, 2012, 27f, Universidade Federal de Uberlândia, Uberlândia, 2012.

PORTAL DO AGRONEGOCIO. disponível em: http://www.portaldoagronegocio.com.br/ Acesso em: 10 Fev 2017.

TONINI, M. G. O et al. Origem e distribuição do plexo lombossacral da paca(Cuniculus paca, LINNEAUS, 1758). Biotemas, Florianópolis, v. 27, n. 2, 157-162, 2014. https://doi.org/10.5007/2175-7925.2014v27n2p157 